\title{
Biosurfactant from Lactobacillus sp. as an antibiofilm agent
}

\author{
SUKHMINDERJIT KAUR *, RAJINDER KAUR \\ Chandigarh University, Chandigarh, India
}

\begin{abstract}
In the era of antibiotic resistance, probiotics have emerged as potential therapeutic alternatives to antibiotics. The probiotic potential of Lactobacillus is well known, but it is also a promising source of novel pharmaceutical products and is used in various food applications such as functional foods, antibiofilm agents, and antimicrobials. Moreover, the synthesis of various chemicals, pharmaceuticals, organic acids, biosurfactants, and bacteriocins from these bacteria has been previously reported. Because of the increasing occurrence of antibiotic resistance, biofilm infections are remarkably difficult to treat. Furthermore, recent studies have acknowledged the role of biosurfactants released by Lactobacillus sp. in restricting the development of biofilms owing to their well-known activity as a biosurfactant in biomedical and food processing industries. Biosurfactants produced by Lactobacillus $\mathrm{sp}$. have shown antimicrobial activity by interfering with the biofilm formation; therefore, it is important to understand the role of biosurfactants from Lactobacillus sp. as antibiofilm agents. In this review, we attempt to focus on the problems associated with the production of pathogenic biofilms in the biomedical sciences and food industry. Furthermore, the importance of biosurfactants from probiotic Lactobacillus sp. in inhibiting biofilm production has also been discussed.
\end{abstract}

Key words: probiotics, biofilms, biosurfactants, antibiofilm agents, Lactobacillus

\section{Introduction}

Lactobacilli are probiotic bacteria that are a part of the normal mucosal microbiota of humans. Various strains of Lactobacillus are important for maintaining gastrointestinal health and preventing inflammatory bowel diseases and intestinal infections (Walter, 2008). Because of their antimicrobial activities, non-toxic nature, and few or no side effects (Butaye et al., 2003), probiotics have emerged as an alternative to antibiotics (Butler et al., 2012). Recently, Lactobacillus sp. have been reported to have the capability of hindering the adhesion of pathogens to epithelial cells lining the intestinal and urogenital tracts, as well as inhibit the biofilm formation on catheters, ventilators, surgical implants, and voice prostheses (Tahmourespour and Kermanshahi, 2011; Taheur et al., 2016). In a hostile environment and under nutrient-deficient conditions, microbes have a tendency to secrete polysaccharide matrices to which bacteria adhere and form an irreversible matured microbial community known as a biofilm. Note that adherence to surfaces changes the behavior of microbes (Garrett et al., 2008). Moreover, the microbes in the biofilm are metabolically active at the top of the biofilm whereas they become dormant at the bottom of the biofilm. These dormant cells are resistant to all chemicals and environmental factors. The metabolic activity of microbes decreases in gradient manner from top to bottom in biofilm as reported by Fux et al. (2005). A biofilm acts as a source of nutrient acquisition, which is important for bacterial growth on surfaces when the nutrient supply is limited. Probiotics such as bacteria belonging to the genera Lactobacillus release certain metabolites that reduce the adhesion of pathogens to surface structures. Note that biosurfactants are extensively used in food and biomedical industries; however, the importance of biosurfactants produced by Lactobacillus still needs to be explored further. This study provides an overview to various problems associated with biofilm

\footnotetext{
* Corresponding author: Chandigarh University, Chandigarh, India; e-mail: sukhminderjit.uibt@cumail.in
} 
formation in biomedical sciences and food industry and how biosurfactants from Lactobacillus can prevent biofilm formation by pathogenic microorganisms. Note that this review provides a comprehensive report of the recent studies that focused on the role of Lactobacillus biosurfactants in inhibiting biofilm production.

\section{Biofilms formation: a concern for food and medical industry}

A biofilm can be defined as a sessile microbial community, characterized by cells attached to a substratum, interface, or to each other (Donlan, 2002). Adherent cells embedded in a matrix of slimy extracellular polymeric substance exhibit an altered phenotype of growth and gene expression (Donlan and Costerton, 2002). The biofilm shares nutrients and provides shelter from adverse environmental conditions such as desiccation and antibiotics (Bendaoud et al., 2011; Rouabhia and Chmielewski, 2012). The clearance of biofilms is a challenging process because antibiotics are less effective against them (Donlan and Costerton, 2002); hence, biofilm infections are remarkably difficult to treat. The National Institute of Health reports that the formation of biofilms and their persistence causes more than $75 \%$ of human infections (Miquel et al., 2016). Many infections associated with medical devices and food contact surfaces can be attributed to biofilm formations by microbes (Phillips et al., 2015). The formation of biofilms starts when the organic matter present in food gets deposited on the surface of the equipment and forms a conditioning film that attracts biologically active microorganisms. The bacteria then become attached to the surface using extracellular filamentous appendages such as flagella and pili. This initial attachment is reversible and is followed by an irreversible microcolony formation. The persistent microbial growth (apart from cleaning and sanitizing) initiates both maturation and differentiation of biofilm, as shown in Figure 1. The expression of genes and quorum sensing leads to the final formation of the biofilm (Shi and Zhu, 2009).

\section{Problems caused by biofilms in food and medical industries}

\section{In food industry}

Biofilms form on critical locations in food processing industries where nutrients are available and where clean- ing and decontamination processes are insufficient. Biofilm formation leads to a number of problems such as product spoilage, food safety problems, impaired heat transfer processes, increasing rate of corrosion on surfaces and loss of production efficiency (Anand and Singh, 2013; Kretli and Dietary, 2016). In the food industry, and especially milk industry, biofilm formations can cause serious technical problems such as decreasing the heat flow across a surface and increasing fluid frictional resistance of surfaces and then increasing the corrosion rate of surfaces, which ultimately leads to energy and production losses (Verran and Jones, 2000). Pathogenic microorganisms growing on food surfaces can crosscontaminate food processing environments and can seed post-processing contamination (Ganesh and Anand, 1998; Chye et al., 2004).

\section{In medical industry}

Biofilm-associated microorganisms attach to both abiotic and biotic surfaces; therefore, biofilms are commonly found to be associated with the development of several nosocomial infections such as wound infections and medical device-related infections (Sambanthamoorthy et al., 2014). Biofilm forming methicillin-resistant Staphylococcus aureus is the most common cause of nosocomial infections (Salgado et al., 2003). Other high biofilm producers such as Pseudomonas aeruginosa, Escherichia coli, and Klebsiella pneumonia are common etiological agents of nosocomial infections (Miquel et al., 2016). The association of medical device-related infections with biofilms was first recognized in 1972 (Johanson et al., 1972). Surgical instruments such as scalpels and fluid lines such as drips and catheters are common sources of biofilm-associated infections. Furthermore, catheters, cardiac pacemakers, and other polymeric medical devices are most likely to be associated with the development of biofilms (Percival et al., 2015). Table 1 lists various medical device-related problems associated with biofilm-forming pathogens.

\section{Lactobacillus derived biosurfactants as antibiofilm and antimicrobial agents}

Taxonomically, the genus Lactobacillus belongs to the phylum Firmicutes, class Bacilli, order Lactobacillales, and family Lactobacillaceae. Lactobacillus is a part of human microflora in the digestive, genital, and urinary 


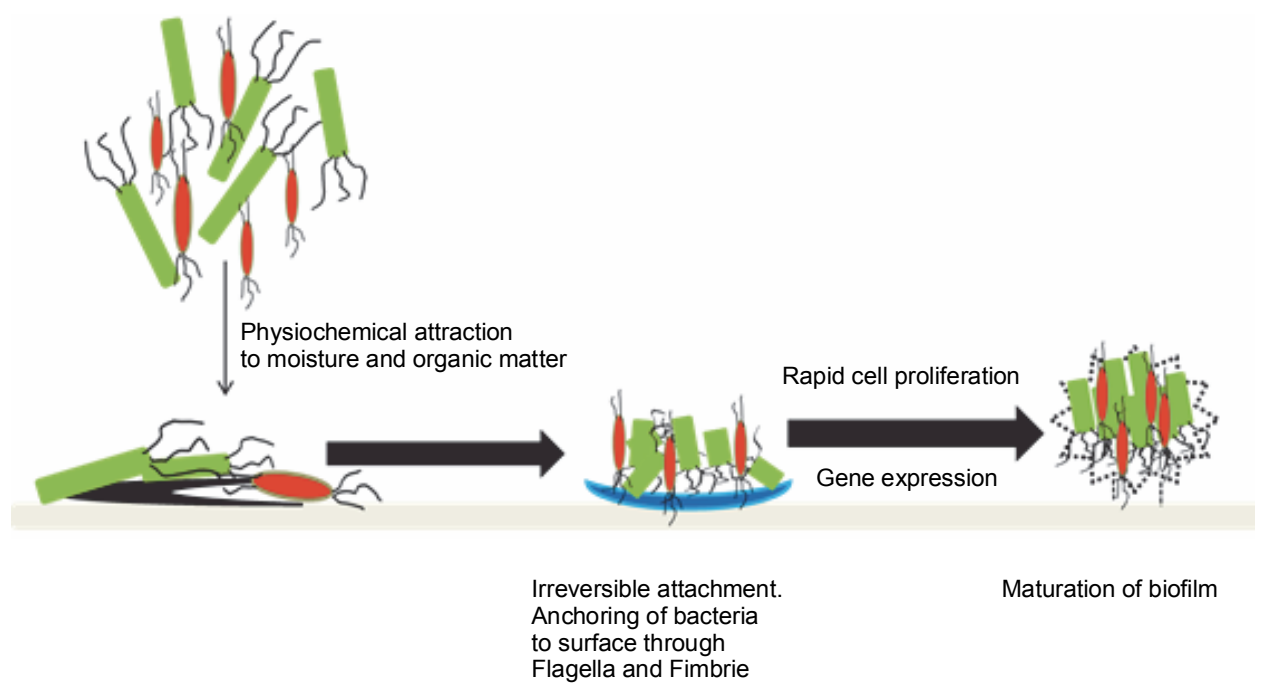

Fig. 1. Biofilm formation on biotic and abiotic surfaces

Table 1. Medical devices related problems associated with biofilms

\begin{tabular}{|c|c|c|c|}
\hline No. & Medicine related infections & Microorganism & Reference \\
\hline 1. & $\begin{array}{l}\text { CAUTI } \\
\text { (Catheter Associated Urinary Tract Infections) }\end{array}$ & $\begin{array}{l}K . \text { pneumoniae, } P \text {. aeruginosa, } \\
S . \text { aureus, } S . \text { epidermidis }\end{array}$ & Percival et al., 2015 \\
\hline 2. & Central-line-associated septicaemia & $\begin{array}{l}C . \text { albicans, } K \text {. pneumoniae, } P \text {. aeruginosa, } \\
S . \text { aureus, } S \text {. epidermidis }\end{array}$ & Larsen et al., 2008 \\
\hline 3. & $\begin{array}{l}\text { VAP } \\
\text { (Ventilator Associated Pneumonia) }\end{array}$ & $\begin{array}{l}\text { Candida sp., } K . \text { pneumoniae, } \\
P . \text { aeruginosa, } S \text {. aureus, } S \text {. epidermidis }\end{array}$ & Singhai et al., 2012 \\
\hline
\end{tabular}

systems (Walter, 2008). Its role as a probiotic is well known (Gu et al., 2008) and Lactobacillus probiotics are extensively used for improving oral health and treating periodontal diseases (Singh et al., 2013). They also provide resistance to gastroenteric pathogens (Prabhurajeshwar and Chandrakanth, 2017). Some Lactobacillus strains that were used as probiotics include LactobacilIus rhamnosus, Lactobacillus plantarum, and Lactobacillus reuteri (Soderliing et al., 2011). There are numerous reports that demonstrate the antimicrobial activity of Lactobacillus, confirming their usefulness for human health (Sambanthmoorthy et al., 2014; Eid et al., 2016).

In addition to providing resistance against pathogens by showing an antagonistic activity, adjuvant effect, systemic immune effect, and competitive exclusion $(\mathrm{Ku}-$ mar and Vandana 2013), Lactobacillus exhibits therapeutic activity by nutritional enhancement, lowering cholesterol levels, ameliorating some types of cancers, and fighting against antibiotic-associated diarrhoea (Kaur et al., 2011).
Lactobacillus prevents pathogenic bacteria from adhering to the intestine by enhancing the systemic immune response and increasing the production of IgA and IgM antibodies (Chen and Chen, 2007; Vuotto et al., 2014). Lactobacillus are involved in alleviating food allergy symptoms in infants by immunomodulation, in lowering serum cholesterol, in improving lactose tolerance, and in reducing risk factors for colon cancer (Cremonini et al., 2002; Fijan, 2014). Lactobacillus probiotics are very effective for preventing urogenital infections by inhibiting their adhesion to the urinary and vaginal tract cells (Kaur et al., 2014).

Recently, because of emerging infections and an increasing antibiotic resistance, the use of probiotics over antibiotics has become more acceptable (Nami et al., 2015; Butler et al., 2012). Acceptability and success rates of probiotics are high because they are nonpathogenic, nontoxic, and do not pose any adverse side effects (Butaye et al.2003). Recently, few studies have reported on the antibiofilm activity of some Lactobacillus species 


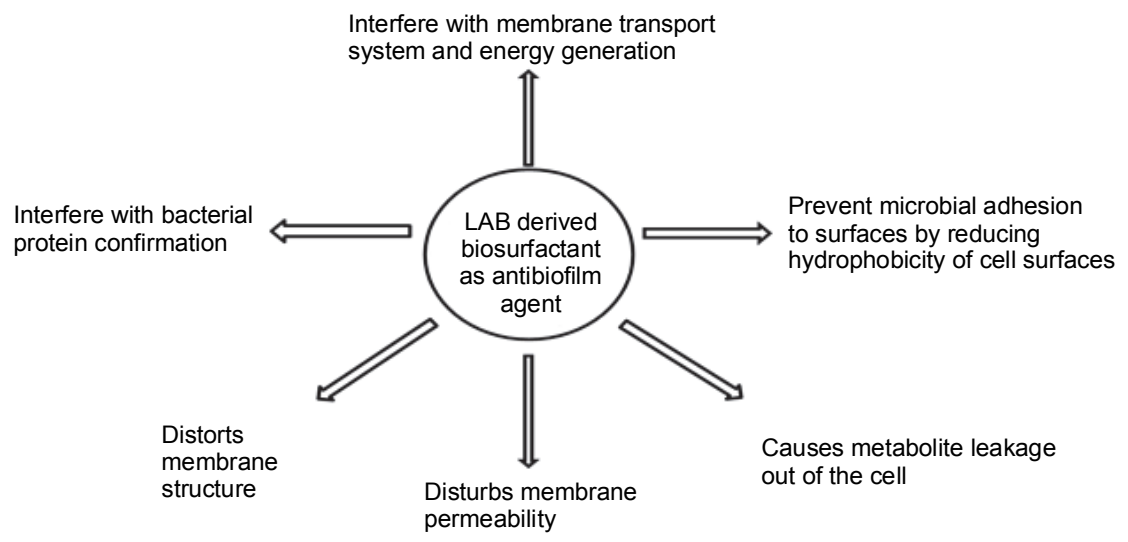

Fig. 2. Approaches of biofilm inhibition by Lactobacillus derived biosurfactants.

Table 2. Biofilm inhibition by Lactobacillus sp.

\begin{tabular}{|c|c|c|c|c|}
\hline No. & Lactobacillus sp. & Biofilm forming pathogens & Results & References \\
\hline 1. & L. fermentum & K. pneumoniae & $\begin{array}{l}\text { acid and neutralized supernatants } \\
\text { of the cells have a potential inhibi- } \\
\text { tory effect against biofilm }\end{array}$ & Maldonado et al. 2007 \\
\hline 2. & $\begin{array}{l}\text { L. lactis, } \\
\text { L. delbrecukii } \\
\text { Enterococcus feacium }\end{array}$ & $\begin{array}{l}\text { B. subtilis, S. sureus, } \\
\text { S. typhi, E.coli }\end{array}$ & $\begin{array}{l}\text { cell-free supernatant (CFS) inhibi- } \\
\text { ted the growth of gram positive } \\
\text { and gram negative bacteria }\end{array}$ & Salih et al. 2011 \\
\hline 3. & L. paracasei & $\begin{array}{l}\text { C. albicans, E.coli, } \\
\text { S. epidermis }\end{array}$ & $\begin{array}{l}\text { isolated biosurfactant exhibited } \\
\text { antimicrobial, anti-adhesive activi- } \\
\text { ties microorganisms }\end{array}$ & Gudina et al. 2010 \\
\hline 4. & L. acidophilus & $\begin{array}{l}\text { S. aureus } \\
\text { S. epidermidis }\end{array}$ & $\begin{array}{l}\text { isolated surfactants inhibited bio- } \\
\text { film formation, development and } \\
\text { maturation }\end{array}$ & Walencka et al. 2008 \\
\hline 5. & $\begin{array}{l}\text { Lactobacillus derived } \\
\text { biosurfactants }\end{array}$ & C. albicans & $\begin{array}{l}\text { the extracted biosurfactant signi- } \\
\text { ficantly reduced the biofilm forma- } \\
\text { tion by } 82 \% \text { at concentration of } \\
312.5 \mu \mathrm{g} / \mathrm{ml}\end{array}$ & Fracchia et al. 2010 \\
\hline 6. & $\begin{array}{l}\text { L. jensenii } \\
\text { L. rhamnosus }\end{array}$ & $\begin{array}{l}\text { multidrug resistant (MDR) strains } \\
\text { of Acinetobacter baumannii, } \\
\text { S. aureus (MRSA) and E.coli. }\end{array}$ & $\begin{array}{l}\text { biosurfactants exhibited anti- } \\
\text { microbial, anti-adhesive and anti- } \\
\text { biofilm activities by causing pro- } \\
\text { nounced membrane damage for } \\
\text { A. baumannï and } S \text {. aureus }\end{array}$ & $\begin{array}{l}\text { Smabanthmoorty et al. } \\
2014\end{array}$ \\
\hline 7. & L. brevis & $\begin{array}{l}\text { B. cereus, } \\
\text { S. salivaris }\end{array}$ & $\begin{array}{l}\text { inhibited biofilm formation by } \\
28.16-42.28 \%\end{array}$ & Taheur et al. 2016 \\
\hline 8. & L. plantarum & multidrug resistance bacteria & $\begin{array}{l}\text { secreted exopolysaccharides re- } \\
\text { duced the cell surface hydrophobi- } \\
\text { city, cell interactions and anti- } \\
\text { biotic resistance patterns }\end{array}$ & Pradeepa et al. 2016 \\
\hline 9. & $\begin{array}{l}\text { L. plantarum } \\
\text { L. pentosus }\end{array}$ & $\begin{array}{l}\text { B. cereus, } \\
P . \text { aeruginosa }\end{array}$ & $\begin{array}{l}\text { cell free supernatant showed anti- } \\
\text { biofilm activity }\end{array}$ & Khiralla et al. 2016 \\
\hline
\end{tabular}


(Tahmourespour and Kermanshahi, 2011; Taheur et al., 2016). The production of biosurfactants represents their inherent capacity to interfere with pathogen colonization. Figure 2 shows the antibiofilm-forming role of Lactobacillius derived biosurfactants.

Recently, it has been reported that Lactobacillus sp. can inhibit biofilm formation by multiple pathogenic microorganisms (Fariq and Saeed, 2016; Khiralla et al., 2016; Satpute et al., 2016). Some studies exhibit the applications of Lactobacillus as antibiofilm and antimicrobial agents; they have been listed in Table 2. Maldonado et al. (2007) found that whole cells of Lactobacillius and its supernatant were successfully employed to treat catheter-associated infections (CAI) caused by Klebsiella. Therefore, Lactobacillius was included into the potential protective microorganisms to be used for bacteriotherapy and prevent CAI and urinary tract infections (Bossa et al. 2017).

Gudina et al. (2010) conducted an important study on the antimicrobial and antiadhesive properties of a biosurfactant isolated from Lactobacillus paracasei against pathogens such as Candida albicans, E. coli, S. aureus, and Staphylococcus epidermidis. The biosurfactant showed antimicrobial activity against all the assayed microorganisms and for twelve of the eighteen microorganisms (such as C. albicans, E. coli, S. aureus, S. epidermidis, and Streptococcus agalactiae). The minimum inhibitory concentration (MIC) and the minimum bactericidal concentration achieved for the biosurfactant ranged between 25 and $50 \mathrm{mg} / \mathrm{ml}$; moreover, the antiadhesive activity against most of the bacterial and fungal strains was evaluated. The authors concluded that the antiadhesive effect was dependent on the microorganism tested and its concentration. High antiadhesive percentages were obtained for $S$. aureus $(76.8 \%), S$. epidermidis $(72.9 \%)$ and $S$. agalactiae (66.6\%); however, low activity was obtained for $P$. aeruginosa (21.2\%) and E. coli (11.8\%). In the same manner, the antiadhesive activity against yeasts and fungal strains was quite low even at the highest biosurfactant concentrations (15.3-38.9\% inhibition).

An analysis of the influence of Lactobacillus acidophilus-derived surfactants on Staphylococcal adhesion and biofilm formation showed antibiofilm and antimicrobial characteristics. Biosurfactants obtained from three $L$. acidophilus strains to inhibit $S$. aureus and $S$. epidermidis biofilms were evaluated. The number of adhering S. aureus and S. epidermidis cells after co-incubation for
$3 \mathrm{~h}$ with biosurfactants reduced by $5-56 \%$ in a strain- and dose-dependent manner. Thus, the $L$. acidophilus-derived surfactants inhibited the bacterial deposition rate and biofilm development; moreover, its maturation did not affect cell growth because of the influence on the cell-surface hydrophobicity of Staphylococci (Walencka et al. 2008).

In a study conducted by Taheur et al. (2016), some strains of lactic acid bacteria (LAB) (Pediococcus pentosaceus $\mathrm{FB} 2, L$. brevis FF2) were isolated from traditional foods such as barley, meat, and fermented olives, and then they were tested for their antibiofilm activities. The results revealed that selected strains were able to inhibit biofilm formation of $B$. cereus ATCC14579 and $S$. salivaris B468. Pradeepa et al. (2016) evaluated the antibiofilm activity of the exopolysaccharide (EPS) isolated from fish-derived $L$. plantarum. The results of this study indicated that EPS exhibited a good antibiofilm activity against biofilm-forming multi-drug resistant bacteria because direct interaction between EPS and pathogenic cell surface led to a reduction in surface hydrophobicity, cell interaction, and antibiotic resistance patterns.

The study by Khiralla et al. (2016) aimed at analyzing the antibiofilm effects of Lactobacillus pentosus and $L$. plantarum $\mathrm{HG}$ against two common pathogens, i.e., $B$. cereus (food-borne pathogen) and $P$. aeruginosa (plant pathogen). Both pathogens showed a significant reduction in biofilm formation in the presence of $20 \mu \mathrm{l}$ cellfree Lactobacillus supernatant.

\section{Lactobacillus-derived biosurfactants and their chemical nature}

Biofilm inhibition by Lactobacillus sp. has been linked to the production of biosurfactants. Microbial surfactants have the potential to reduce a number of biofilm producers, and their anti-adhesive activity helps protect against the harmful effects of biofilm communities (Rodrigues, 2006; Gudina et al., 2010; Das et al., 2013; Fracchia et al., 2010, Saharan et al., 2011).

Biosurfactants are surface-active molecules and a diverse group of chemical compounds are synthesized by bacteria, yeasts, and filamentous fungi (Desai and Banat, 1997; Bhardwaj et al., 2013). Thus, biosurfactants are secondary metabolites with an amphiphilic structure excreted extracellularly by microbial cells. Long-chain of fatty acids, hydroxyl fatty acids, or $\alpha$-alkyl- $\beta$-hydroxy fatty acids form the hydrophobic moiety of the biosurfactant. 
Carbohydrate, amino acid, cyclic peptide, phosphate, carboxylic acid, or alcohol are the hydrophilic moieties of biosurfactant (Rufino et al., 2008). Because of the presence of both hydrophobic and hydrophilic domains in amphipathic molecules, biosurfactants accumulate between fluid phases and hence reduce surface and interfacial tensions (Karanth et al., 1999).

Different Lactobacillus sp. produce biosurfactants with characteristic biochemical compositions. Biosurfactants produced by L. paracasei, Lactobacillus lactis, and $L$. pentosus are either glycoproteins or glycolipopeptides. Lactobacillus helveticus-derived biosurfactants are mainly lipids and sugars, whereas biosurfactants produced by $L$. plantarum are glycoproteic (Sauvageau et al., 2012) or glycolipidic (Madhu and Prapulla, 2014).

Falagas and Makris (2009) identified the role of probiotics (primarily Lactobacillus sp.) in vitro to inhibit biofilm formation on abiotic surfaces such as voice prosthesis and catheters. Sharma and Saharan (2014) isolated LAB from raw milk samples collected from local dairy farms of Haryana, India, and then screened them for simultaneous production of biosurfactants and bacteriocins. They found that, similar to glycolipids, the biosurfactants produced were a mixture of lipids and sugars.

Tahmourespour et al. (2011) performed a study on the effect of $L$. acidophilus-derived biosurfactant on glucosyltransferase B (Gtf $B)$ and glucosyltransferase C ( $G t f C$ ) gene expression in Streptococcus mutans biofilm. The Fourier transform infrared (FTIR) analysis of biosurfactants produced by $L$. acidophilus confirmed that they have a protein-like component; however, Rodrigues et al. (2006) reported that the biosurfactant produced by L. lactis 53 has a glycoprotein-like nature.

Based on the chemical structure and mode of action, different types of biosurfactants have been reported in Lactobacillius sp. (Satpute et al., 2016). Lactobacillius derived biosurfactants can be complex molecules composed of carbohydrates, proteins, lipids, and/or combinations of carbohydrates and lipids molecules with or without phosphorus groups (Saravanakumari and Mani, 2010). However, compared to glycoproteins and glycolipids, cells associated with proteinaceous biosurfactants have been extensively reported in the literature. In biosurfactants (amphiphilic compounds), lipids form the hydrophobic chain, while the hydrophilic chain is composed of proteins and sugars. Glycolipid-based biosurfactants such as rhamnolipids and surfactin are classified as

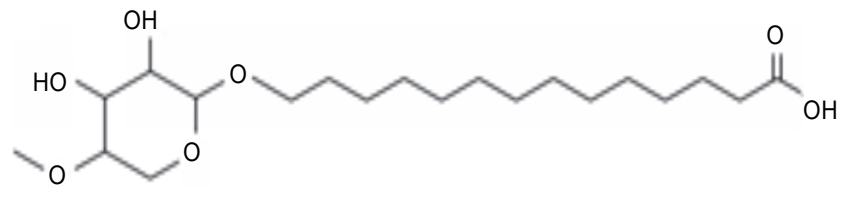

Fig. 3. Structure of L. helveticus derived biosurfactant (Sharma et al. 2014)

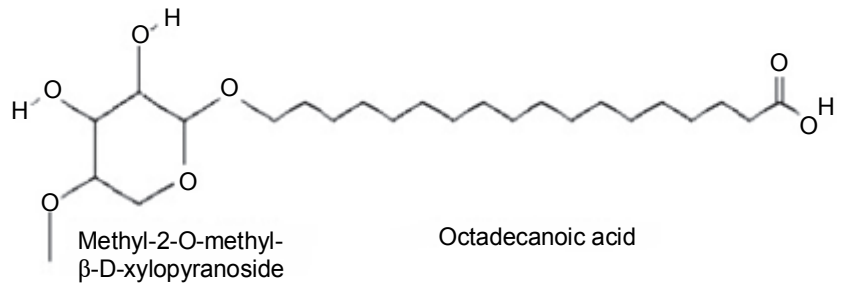

Fig. 4. Structure of $L$. lactis derived biosurfactant (Saravanakumari and Mani, 2010)

low molecular weight biosurfactants; however, glycolipopeptides are classified as high molecular weight biosurfactants. A number of studies have reported the production of biosurfactants from Lactobacillius; however, the paucity of structural and molecular knowledge has limited their commercial production for use in pharmaceuticals (Karanth et al. 1999; Madhu and Prapulla 2014; Sharma and Saharan 2014; Satpute et al. 2016). Sharma et al. (2014) studied the structural characteristics of L. helveticus MRTL9-derived biosurfactant using FTIR, nuclear magnetic resonance (NMR) spectroscopy, and gas chromatography-mass spectrometry (GCMS). They confirmed the presence of sugar and octadecanoic acid containing glycolipid with a cumulative molecular weight (MW) of $391.32 \mathrm{~m} / \mathrm{z}$ and identified its structure, which is shown in Figure 3.

The structure of the biosurfactant studied by Sharma et al. (2014) was similar to that of the L. lactis-derived biosurfactant predicted by Saravanakumari and Mani (2010). It was detected using GCMS and NMR studies and found to be a xylolipid consisting of methyl-2-Omethyl-beta-d-xylopyranoside linked with octadecanoic acid, with a MW of $476 \mathrm{~g} / \mathrm{mol}$ (Fig. 4).

Recently, Abdalsadiq et al. (2018) analyzed the structure of a biosurfactant fraction from $L$. pentosus by liquid chromatography-mass spectrometry and identified it to be a glycoglycerolipid containing 6-O-acyl- $\alpha$-D-glucopyranosyldiglyceride. However, the biosurfactant from L. casei had a high polysaccharide and phosphate content (Velraeds et al., 1996). 
Tahmourespour et al. (2011) studied the effect of L. acidophilus-derived biosurfactant on $S$. mutans biofilm formation and characterized it to be composed of proteins rather than polysaccharides and phosphates. Note that biosurfactants from L. acidophilus RC14 and L. fermentum B54 were rich in proteins as studied by FTIR and X-ray photoelectron spectroscopy. Abdalsadiq et al. (2018) identified the structure of $L$. acidophilus based biosurfactants by MS to be composed of lipids and proteins. Moreover, they characterized the biosurfactant to be a lipopeptide compound containing nine amino acids and $\mathrm{C} 12-\mathrm{C} 17 \beta$-hydroxy fatty acids.

\section{Conclusions}

Biosurfactants of Lactobacillus origin have emerged to be promising antimicrobial and antibiofilm agents that can be used in food processing and biomedical sciences. Recently, studies have shown that Lactobacillus-derived biosurfactants can be effectively used as protective biocoating agents in medical practice and as devices and anti-adhesive agents in food processing industries. In this report, we reviewed the importance of Lactobacillus derived biosurfactants and obtained insights into their biochemical structure. Although a large amount of literature has explored the antibiofilm and antimicrobial potential of biosurfactants, their structure needs to be thoroughly investigated. Furthermore, to enhance their antimicrobial and antibiofilm potential, future studies need to focus on the structural aspects of Lactobacillus derived biosurfactants and the chemical modifications in their structure.

\section{References}

Abdalsadiq N., Hassan Z., Lani M., Bulgasem B. (2018) Identification of biosurfactant produced by Lactobacillus sp. using mass spectrometry. Res. J. Life Sci. Boinform. Pharm. Chem. Sci. 4: 247-258.

Anand S., Singh D. (2013) Resistance of the constitutive microflora of biofilms formed on whey reverse-osmosis membranes to individual cleaning steps of a typical cleanin-place protocol. J. Dairy Sci. 96: 6213-6222.

Bendaoud M., Vinogradov E., Balashova N.V., Kadouri D.E., Kachlany S.C., Kaplan J.B. (2011) Broad spectrum biofilm inhibition by Kingellakingae exopolysaccharide. J. Bacteriol. 193: 3879-3886.

Bhardwaj G., Cameotra S. S., Chopra H.K. (2013) Biosurfactants from fungi: a review. Pet. Environ. Biotechnol. 4: 6 .

Bossa L., Kline K., McDougald D., Lee B.B., Rice S.A. (2017) Urinary catheter-associated microbiota change in accor- dance with treatment and infection status. PLos One. 12: e0177633.

Butaye P., Devereise L.A., Heasebrouck F. (2003) Antimicrobial growth promoters used in animal feed; effects of less well known antibiotics on Gram positive bacteria. Clin. Microbiol. Rev. 16: 175-188.

Butler C.C., Duncan D., Hood K. (2012) Does taking probiotics routinely with antibiotics prevent antibiotic associated diarrhea? BMJ 344: 682.

Chen M.J., Chen K.N. (2007) Applications of probiotic encapsulation in dairy products. New York: Wiley-Blackwell.

Chye F.Y.F., Abdullah A., Ayob M.K. (2004) Bacteriological quality and safety of raw milk in Malaysia. Food Microbiol. 21: 535-541.

Cremonini F., Di Caro S., Nista E.C. (2002) Meta-analysis: the effect of probiotic administration on antibiotic-associated diarrhea. Aliment. Pharmacol. Ther. 16: 1461-1467.

Das J.K., Mishra D., Ray P., Tripathy P., Beuria T.K., Singh N., Suar M. (2013) In vitro evaluation of anti-infective activity of a Lactobacillus plantarum strain against serovar Enteritidis. Gut Pathog. 5: 11-20.

Desai J.D., Banat I.M. (1997) Microbial production of surfactants and their commercial potential. Microbiol. Mol. Biol. Rev. 61: 47-64.

Donlan R.M. (2002) Biofilms: microbial life on surfaces. Emerg. Infect. Dis. 8: 881.

Donlan R.M., Costerton J.W. (2002) Biofilms: survival mechanisms of clinically relevant microorganisms. Clin. Microbiol. Rev. 15: 167-193.

Eid R., El Jakee J., Rashidy A., Asfour H., Omara S. (2016) Potential antimicrobial activities of probiotic Lactobacillus strains isolated from raw milk. J. Prob. Health. 4(2): 1-8.

Falagas M.E., Makris G.C. (2009) Probiotic bacteria and biosurfactants for nosocomial infection control: a hypothesis. J. Hosp. Infect. 71(4): 301-306.

Fariq A., Saeed A. (2016) Production and biomedical applications of probiotic biosurfactants. Curr. Microbiol. 72: $489-495$.

Fijan S. (2014) Microorganisms with claimed probiotic properties: an overview of recent literature. Int. J. Environ. Res. 11: 4745-4767.

Food and Agricultural Organization of the United Nations. World Health Organization (2002) Guidelines for the evaluation of probiotics in food.Report of a joint FAO/WHO working group on drafting guidelines for the evaluation of probiotics in food. Ontario, Canada: 1-11.

Fracchia L., Cavallo M., Allegrone G.,Martinotti M.G. (2010) A Lactobacillus-derived biosurfactant inhibits biofilm formation of human pathogenic Candida albicans biofilm producers. Appl. Microbiol. Biotechnol. 2: 827-837.

Fux C.A., Costerton J.W., Stewart P.S., Stoodley P. (2005) Survival strategies of infectious biofilms. Curr. Trends. Microbiol. 13: 34-40.

Ganesh C.K., Anand S.K. (1998) Significance of microbial biofilms in food industry a review. Int. J. Food Microbiol. 42: $9-27$. 
Garrett T.R., Bhakoo M., Zhang Z. (2008) Bacterial adhesion and biofilms on surfaces. Pro. Nat. Sci.18: 1049-1056.

Gu R.X., Yang Z.Q., Li, Z.H., Chen, S.L., Luo, Z.L. (2008) Probiotic properties of lactic acid bacteria isolated from stool samples of longevous people in regions of Hotan, Xinjiang and Bama, Guangxi, China. Anaerobe14: 313-317.

Gudina E.J., Teixeira J.A., Rodrigues L.R. (2010) Isolation and functional characterization of a biosurfactant produced by Lactobacillus paracasei. Colloid. Surf. Biointerfaces 76: 298-304.

Johanson W.G., Pierce A.K., Sanford J.P., Thomas G.D. (1972) Nosocomial respiratory infections with Gram-negative bacilli: The significance of colonization of the respiratory tract. Ann. Int. Med. 77: 701-706.

Karanth N.G.K., Deo P.G., Veenanadig N.K. (1999) Microbial production of biosurfactants and their importance. Curr. Sci. 77: 116-123.

Kaur A., Arora M., Pandove G. (2014) Probiotics and its health benefits. J. Global Biosci. 3(3): 686-693.

Kaur S., Vaishnavi C., Prasad K.K., Ray P., Kochhar R. (2011) Effect of Lactobacillus acidophilus \& epidermal growth factor on experimentally induced Clostridium difficile infection. Indian J. Med. Res. 133: 434-441.

Khiralla G.M., Mohamed E.A.H., Farag A.G., Elhariry H. (2016) Antibiofilm effect of Lactobacillus pentosus and Lactobacillus plantarum cell-free supernatants against some bacterial pathogens. J. Biotech. Res. 6: 86-95.

Kretli L., Dietary W. (2016) Microbial biofilms: the challenge of food industry. Biochem. Mol. Biol. J. 1: 1.

Kumar A., Vandana (2013) Probiotics: nature's medicine. Int. J. Nutr. Pharmacol. Neurol. Dis. 3: 219-228.

Madhu A.N., Prapulla S.G. (2014) Evaluation and functional characterization of a biosurfactant produced by LactobacilIus plantarum CFR 2194. Appl. Biochem. Biotechnol. 172: 1777-1789.

Maldonado N.C., Silva D.R., Cecilia M., Nader M.M.E. (2007) A simple technique to detect Klebsiella biofilm forming strains. Inhibitory potential of Lactobacillus fermentum CRL 1058 whole cells and products. Commun. Curr. Res. Edu. Topics Trends Appl. Microbiol., Mendez Vilas (Ed.): 52-59.

MiquelS., LagrafeuilleR., Souweine B., Forestier C. (2016) Antibiofilm activity as a health issue. Front Microbiol. 7: 1-14.

Nami Y., Haghshenas B., Abdullah N., Barzegari A., Radiah D., Rosli R., Khosroushahi A.Y. (2015) Probiotics or antibiotics: future challenges in medicine. J. Med. Microbiol. 64: 137-146.

Percival S.L., Suleman L., Vuotto C. Donelli G. (2015) Healthcare-associated infections, medical devices and biofilms: risk, tolerance and control. J. Med. Microbiol. 64: 323-334.

Phillips K.S., Patwardhan D. Jayan G. (2015) Biofilms, medical devices, and antibiofilm technology: key messages from a recent public workshop. Am. J. Infect. Control. 43: 2-3.

Prabhurajeshwar C., Chandrakanth R.K. (2017) Probiotic potential of Lactobacillius with antagonistic activity against pathogenic strains: An in vitro validation for the production of inhibitory substances. Biomed. J. 40: 270-283.
Pradeepa S.A.D., Matthews K., HegdeA.R., AkshathaB., Mathias A.B., MutalikS., VidyaS.M. (2016) Multidrug resistant pathogenic bacterial biofilm inhibition by Lactobacillus plantarum exopolysaccharide. Bioact. Carbo. Diet. Fibre. 8: 17-14.

Rodrigues L.R., Banat I.M., Teixeira J.A. Oliveira R. (2006) Biosurfactants: potential applications in medicine. J. Antimicrob. Chemother. 57(4): 609-618.

Rouabhia M., Chmielewski W. (2012) Diseases associated with oral polymicrobial biofilms. The Open Mycol. J. 6: 27-32.

Rufino R.D., Sarubbo L.A., Campos-Takaki G.M. (2007) Enhancement of stability of biosurfactant produced by Candida lipolytica using industrial. 28 Biotechnology. Vol. 11: Bioremediation residue as substrate. World J. Microbiol. Biotechnol. 23: 729-734.

Saharan B.S., Sahu R.K., Sharma D. (2011) A review on biosurfactants: fermentation, current developments and perspectives. Genetic Engg. Biotechnol. J. 14: 1-18.

Salgado C.D., Farr B.M. Calfee D.P. (2003) Communityacquired methicillin-resistant Staphylococcus aureus: a meta-analysis of prevalence and risk factors. Clin. Infect. Dis. 36: 131-139.

Sambanthamoorthy K., Feng X., Patel R., Patel S., Paranavitara C. (2014) Antimicrobial and antibiofilm potential of biosurfactants isolated from Lactobacillius against multidrug-resistant pathogens. BMC Microbiol. 14: 197.

Saravanakumari P., Mani K. (2010) Structural characterization of a novel xylolipid biosurfactant from Lactococcus lactis and analysis of antibacterial activity against multi-drug resistant pathogens. Biores technol. 101: 8851-8854.

Satpute S.K., Kulkarni G.R., Banpurkar A.G., Banat I.M., Mone N.S., Patil R.H., Cameotra S.S. (2016) Biosurfactants from Lactobacillius species: Properties, challenges and potential biomedical applications. J. Basic Microbiol. 56: 1-19.

Sauvageau J., Ryan J., Lagutin K., Sims I.M., Stocker B.L., Tiommer M.S. (2012) Isolation and structural characterization of the major glycolipids from Lactobacillus plantarum. Carbohydrate Res. 357: 151-156.

Sharma D., Saharan B.S. (2014) Simultaneous production of biosurfactants and bacteriocins by probiotic Lactobacillus casei MRTL3. Int. J. Microbiol. 1: 1-7.

Sharma D., Saharan B.S., Chauhan N., Bansal A., Procha, S. (2014) Production and structural characterization of Lactobacillus helveticus derived biosurfactant. Sci. World J. 2014: 1-9.

Shi X., Zhu X. (2009) Biofilm formation and food safety in food industries. Trends Food Sci. Technol. 20: 1-7.

Singh V.P., Sharma J., Babu S., Rizwanulla S.A. (2013) Role of probiotics in health and diseases: a review. J. Pak. Med. Assoc. 63: 253-257.

Soderliing E.M., Martinnen, Haukioja A.L. (2011) Probiotic Lactobacillus interferes with Streptococcus mutans biofilm formation in vitro. Curr. Microbiol. 62: 618-622.

Taheur B.F., Kouidhi B., Fdhila K., Elabed H., Slama B.R., Mahdouani K., Bakhrouf A., Chaieb K. (2016) Anti-bac- 
terial and anti-biofilm activity of probiotic bacteria against oral pathogens. Microb. Pathog. 97: 213-220.

Tahmourespour A., Kermanshahi R.K. (2011) The effect of a probiotic strain (Lactobacillus acidophilus) on the plaque formation of oral Streptococci. Bosnian J. Basic Med. Sci. 11: 37-40.

Tahmourespour A., Salehi R., Kermanshahi R.K. (2011) Lactobacillus acidophilus-derived biosurfactant effect on gtfB and gtfC expression level in Streptococcus mutans biofilm cells. Brazil J. Microbiol. 42: 330-339.

Velraeds M.M., Van der Mei H.C., Reid G., Busscher H.J. (1996) Inhibition of initial adhesion of uropathogenic Enterococcus faecalis by biosurfactants from Lactobacillus isolates. Appl. Environ. Microbiol. 62: 1958-1963.
Verran J., Jones M. (2000) Industrial biofouling. New York: John Wiley and Sons Ltd.

Vuotto C., Longo F., Donelli G. (2014) Probiotics to counteract biofilm-associated infections: promising and conflicting data. Int. J. Oral Sci. 6: 189-194.

Walencka E., Różalska S., Sadowska B., Różalska B. (2008) The influence of Lactobacillus acidophilus-derived surfactants on staphylococcal adhesion and biofilm formation. Folia Microbiol. 53: 61.

Walter J. (2008) Ecological role of Lactobacillius in the gastrointestinal tract: implications for fundamental and biomedical research. Appl. Environ. Microbiol. 74: 4985-4996. 